\title{
Ciddi bilirübin yüksekliği ile seyreden hipotiroidi olgusu
}

\section{A case with severe hyperbilirubinemia due to hypothyroidism}

\author{
Gökhan DİNDAR, Mesut SEZİKLİ, Emre DÖNMEZ
}

Kocaeli Derince Eğitim ve Araştırma Hastanesi, Gastroenteroloji Kliniği, Kocaeli

Hipotiroidi karaciğer üzerine etkisi rastlantısal karaciğer enzim yüksekliklerinden batında asite kadar değişen klinik spektrum içerebilir. Kolestaz ise çoğunlukla hipertiroidide gözlenmekle birlikte her iki klinik durumda izlenebilir. Sunduğumuz hasta endoskopik retrograd kolanjiopankreatografi amaçlı yönlendirilen fakat takiplerinde intrahepatik kolestaz saptanan ve hipotiroidi tedavisi ile tamamen düzelen bir vaka idi. Literatürde ciddi bilirübin yükseklikleri tiroid hastalıklarında nadiren izlenir. Genellikle de hipertiroidide eşlik eder. Hipotiroidide ılımlı enzim yüksekliği ve bilirübin yüksekliği saptansa da bizim vakamızda olduğu gibi 20'li değerlerde bilirübin yüksekliğini literatüre ilk defa sunuyoruz.

Anahtar kelimeler: Hipotiroidi, hiperbilirübinemi

\section{GİRISS}

Karaciğer, tiroid hormonlarının transport, depolanma, metabolizma ve itrahında önemli bir yere sahiptir. Tirod hormon bozukluklarının karaciğer üzerine etkisi ise çeşitlidir. Rastlantısal karaciğer enzim yüksekliklerinden batında asite kadar değişen klinik spektrum içerebilir. Kolestaz ise çoğunlukla hipertiroidide gözlenmekle birlikte her iki klinik durumda izlenebilir. Biz ağır hiperbilirübinemi ile başvuran ve tiroid hormon replasmanı ile tamamen normale dönen bir olgu sunduk.

\section{OLGU SUNUMU}

Son 1 haftadır artan ciltte sarılık şikayetiyle dıs merkeze başvuran 50 yaş kadın hasta endoskopik retrograd kolanjiopankreatografi (ERCP) amaçlı gastroenteroloji kliniğine sevk edilmiş. Yüksek ateş, karın ağrısı, ishal, bulantı-kusma tarzında konstitüsyonel semptom tariflemeyen hastanın ilaç toksik madde maruziyeti yoktu. Hastanın menapoz yaşı 47 idi. Hastanın sistemik muayenesinde ciltte ve skleralardaki ikteri dışında patolojik bir bulguya rastlanılmadı. Hastanın tetkiklerine göre alanin aminotrasferaz (ALT): $717 \mathrm{U} / \mathrm{L}$, aspartat aminotransferaz (AST): $963 \mathrm{U} / \mathrm{L}$, gama-glutamil transpeptidaz (GGT): $162 \mathrm{U} / \mathrm{L}$, alkalen fosfataz (ALP): $179 \mathrm{U} / \mathrm{L}$, laktat dehidrogenaz: $145 \mathrm{U} / \mathrm{L}$, total bilirübin: $17,5 \mathrm{mg} / \mathrm{dl}$, direkt bilirübin: $12,3 \mathrm{mg} / \mathrm{dl}$, indirekt bilirübin: $5,2 \mathrm{mg} / \mathrm{dl}$, sedimentasyon $11 \mathrm{~mm} / \mathrm{saat}$, C-reaktif protein $0,4 \mathrm{mg} / \mathrm{L}$ olarak ölçülmüş. Hastaya yapılan üst batın ultrasonografi (USG) görüntülemesinde intrahepatik safra yollarının genişlemiş ol-
Hypothyroidism has diverse effects on the liver, which may manifest themselves in various clinical forms from incidentally elevated liver function tests to ascites. Cholestasis is generally seen in hyperthyroidism and, in rare cases, along with hypothyroidism. We present a case who was referred to us for endoscopic retrograde cholangiopancreatography due to cholestasis. Intrahepatic cholestasis was revealed during follow-up and improved with treatment for hypothyroidism. We rarely encounter severely elevated serum bilirubin levels in patients with hypothyroidism in the literature. In patients with severe hypothyroidism, mild to moderate abnormal liver tests and elevated bilirubin may be seen, but our case had very high bilirubin levels compared with previously presented patients.

Key words: Hypothyroidism, hyperbilirubinemia

duğu; ekstrahepatik safra yollarında ve koledok lümen çaplarında genişleme olmadığı, karaciğer ve pankreas parankiminin doğal olduğu, safra kesesinde taş olmadığı saptandı. Hastanın serolojik incelemesinde anti-HAV immünglobulin M (IgM) negatif, HBc-IgM negatif, sitomegalovirüs (CMV) - IgM negatif, Rubella-IgM negatif, toksoplazma-IgM negatif olarak saptandı. Otoantikor belirteçlerinden anti-düz kas antikoru (ASMA) negatif, liver kidney mikrozomal antikor negatif, anti mitokondrial antikor (AMA) negatif, antinükleer antikor (ANA) negatif olarak saptand.. Hastanın tiroid fonksiyon testlerinde trioid stimulan hormon (TSH): 50,13 micU/ dl, T4: 0,59 ng/dl, T3: 2,13 pg/ml olarak saptandı. Yatışı süresince total bilirübini 20 'li değerlere ulaşan hastanın yükselen uluslararası normalleştirilmiş oran (INR) değeri 3 günlük $\mathrm{K}$ vitamini ile normale geldi. Hastanın $50 \mathrm{mcg} /$ gün dozunda levotiroksin ile tiroid hormon replasmanına başlanıldı. Tedavisinin 4. gününde levotiroksin $100 \mathrm{mcg} /$ gün dozuna yükseltildi. Hastanın tedavisinin 5. gününden itibaren bilirübin ve transaminaz değerlerinde gerileme izlendi [total bilirübin 7 , AST: 215, ALT: 196 (5. gün)].

\section{TARTISSMA}

Kolestaz intra ve ekstra hepatik olabilir. Hastanın kliniği ve başlangıç değerlerini ele aldığımızda ALP ve GGT'nin yüksekliğinin AST, ALT’ye göre göreceli düşük kalması, ağn bulantı kusma vb. şikayetlerinin olmaması ve USG bulguları bizi ekstrahepatik kolestazdan uzaklaştırdı. Klinik pratikte 
ALP ve ALT oranı bize yol gösterir. ALT/ALP > 5 ise bu hepatoselüler tip sarılığı gösterir. Bu oran $<2$ ise kolestatik tip sarılığa işaret eder. Sepsis, ilaç kullanımı, toksik hepatit, viral hepatit vb. intrahepatik kolestaz nedenleri ekarte edilen hastada levotiroksin tedavisi ile bilirübin değerleri geriledi. $\mathrm{Bu}$ nedenle magnetik rezonans kolanjiopankreatografi tetkiki yapılmadı. Bu denli yüksek bilirübin değerleri hipotiroidi seyrinde olağan değildir. Genel olarak hipotiroidizm karaciğer hastalıklarına benzer klinik ile izlenebilir. Hasta yorgunluk, kas krampları myalji gibi şikayetlerin yanısıra karaciğer enzim yüksekliği laboratuvar bulgusu ile karşımıza gelebilir (1). Ileri derece hipotiroidide ise miksödem koması eksüdatif karakterde asit gelişebilir (2,3). Asit genellikle sağ kalp yetmezliğine bağlı ise de yetmezlik gelişmeden de asit gelişen vakalar vardır. Bunun nedeni de vasküler endotelde permeabilite artışına bağlanmıştır (4).

Hipotiroidizmin doğrudan karaciğer yapı veya fonksiyonunu etkileyebileceğine dair kanıtlar da vardır. Hipotirodizmin safra ve bilirübin atılımını engelleyerek kolestatik sarılık yaptığına dair olgu sunumları bulunmaktadır. Deneysel çalışmalarda hipotiroidinin bilirübin UDP-glukuronidaz aktivitesini azaltarak bilirübin ekskresyonunu azalttığını göstermiştir (5). Bu safra akışkanlığı azalması $\mathrm{Na}+, \mathrm{K}+$-ATPase içeren memb-

\section{KAYNAKLAR}

1. Laycock MA, Pascuzzi RM. The neuromuscular effects of hypothyroidism. Semin Neurol 1991;11:288-94.

2. Thobe N, Pilger P, Jones MP. Primary hypothyroidism masquerading as hepatic encephalopathy: case report and review of the literature. Postgrad Med J 2000;76:424-6.

3. Klein I, Levey GS. Unusual manifestations of hypothyroidism. Arch Intern Med 1984; 144:123-8

4. Baker A, Kaplan M, Wolfe H. Central congestive fibrosis of the liver in myxedema ascites. Ann Intern Med 1972;77:927-9

5. Van Steenbergen W, Fevery J, De Vos R, et al. Thyroid hormones and the hepatic handling of bilirubin. I. Effects of hypothyroidism and hyperthyroidism on the hepatic transport of bilirubin mono- and diconjugates in the Wistar rat. Hepatology 1989; 9:314-21. ran taşıyıcılarını ve enzimlerini etkiler. Sonuçta hipotioridi; bilirübin ekskresyon azlığı, hiperkolesterolemi ve safra kesesi hipotonisine neden olur (6). Tüm bu değişiklikler kalıcı karaciğer hasarına neden olmadan tiroid hormon replasmanı ile geriye döner $(7,8)$. Hastamızım miksödem kliniğinde olmaması, ek hipotiroidiye bağlı şikayetlerinin olmaması dikkat çekicidir. Ayrıca literatür tarandığında bu denli bilirübin yüksekliği yapması olağan değildir. Altıntaş ve ark.larının yaptığı bir çalışmada ağır sarılığı olan (>5 mg/dl) hastaların etyolojileri izlendiğinden en sık neden malignensiler ve viral hepatitler bulunmuş, sadece bir vakada hipertiroidi suçlanmıştır (9). Bu denli yüksek bilirübin yüksekliği ile gelen hastada her ne kadar hipotirodi saptansa da diğer nedenler de ekarte edilmelidir. Otoimmün hepatit yine düşünülen bir tanı idi. Otoimmün belirteçler negatif idi. Fakat otoimmün hepatitte ilerleyen dönemlerde pozitifleşebilir. Bu nedenle tam olarak ekarte edilemez. Karaciğer biyopsisi yapılabilirdi. Hastanın kliniğinin rahat olması ve tiroid hormon replasmanı ile bilirübin düzeylerindeki belirgin düşüş sağlanması biyopsi seçeneğini erteletti.

Hipotiroidi günlük pratikte ağır hiperbilirübinemi yapan nedenler arasında nadir de olsa akılda tutulmalıdır.

6. Inkinen J, Sand J, Nordback I. Association between common bile duct stones and treated hypothyroidism. Hepatogastroenterology 2000;47: 919-21.

7. Huang MJ, Liaw YF. Clinical associations between thyroid and liver diseases. J Gastroenterol Hepatol 1995;10:344-50.

8. Gaitan E, Cooper DS. Primary hypothyroidism. Curr Ther Endocrinol Metab 1997;6:94-8

9. Altıntaş E, Tombak A, Tellioğlu B. Ciddi hiperbilirübinemi nedenleri, tanı ve sağaltımı. Akademik Gastroenteroloji Dergisi 2010;9:02-07. 